\title{
ANALISIS PENGARUH AKUNTABILITAS KEUANGAN DAERAH, VALUE FOR MONEY DAN PENGAWASAN TERHADAP REALISASI PENGELOLAAN KEUANGAN DAERAH PADA PEMERINTAH KOTA BANJARBARU TAHUN 2020
}

\author{
Mohammad Noor Afriza \\ Sekolah Tinggi Ilmu Ekonomi Pancasetia Banjarmasin \\ Jl. Ahmad Yani Km. 5.5 Banjarmasin \\ nindievin88@gmail.com
}

\begin{abstract}
Abstrak: Tujuan penelitian adalah 1) untuk mengetahui dan menganalisa pengaruh secara parsial variabel akuntabilitas keuangan daerah terhadap realisasi pengelolaan keuangan daerah di Pemerintah Kota Banjarbaru. 2) untuk mengetahui dan menganalisa pengaruh secara parsial variabel value for Money terhadap realisasi pengelolaan keuangan daerah di Pemerintah Kota Banjarbaru. 3) untuk mengetahui dan menganalisa pengaruh secara parsial variabel pengawasan terhadap realisasi pengelolaan keuangan daerah di Pemerintah Kota Banjarbaru. 4) untuk mengetahui dan menganalisa pengaruh secara simultan variabel akuntabilitas keuangan daerah, value for money, dan pengawasan terhadap realisasi pengelolaan keuangan daerah di Pemerintah Kota Banjarbaru. Penelitian ini merupakan penelitian kuantitatif dengan menggunakan data yang diperoleh dari kuesioner dan diukur dengan menggunakan skala likert. Teknik pengambilan sampel dalam penelitian ini menggunakan purposive sampling. Sampel yang digunakan dalam penelitian ini adalah pegawai Satuan Kerja Perangkat Daerah (SKPD) Kota Banjarbaru yang berkaitan dengan

bidang keuangan sebanyak 62 pegawai. Teknik analisis data yang digunakan yaitu uji regresi linier berganda. Data dianalisis dengan menggunakan software SPSS versi 22. Hasil dari penelitian ini menunjukan bahwa: (1) terdapat pengaruh yang positif dan signifikan antara akuntabilitas keuangan daerah terhadap realisasi pengelolaan keuangan daerah, (2) tidak terdapat pengaruh yang positif dan signifikan antara value for money terhadap realisasi pengelolaan keuangan daerah, (3) terdapat pengaruh yang positif dan signifikan antara pengawasan terhadap realisasi pengelolaan keuangan daerah, (4) terdapat pengaruh yang signifikan antara akuntabilitas keuangan daerah, value for money, dan pengawasan terhadap realisasi pengelolaan keuangan daerah.
\end{abstract}

Kata kunci: akuntabilitas keuangan daerah, value for money, pengawasan 


\section{Latar Belakang}

Pemerintah daerah memiliki tanggung jawab secara terus menerus dalam mewujudkan kepemerintahan yang baik (good governance) untuk membangun negara. Otonomi daerah dan desentralisasi fiskal diberlakukan oleh pemerintah pusat dengan tujuan untuk mengurangi ketergantungan, bahkan menghilangkan ketergantungan pemerintah daerah kepada pemerintah pusat agar dapat memberdayakan daerahnya serta dapat berkompetensi baik di tingkat regional, nasional, maupun internasional (Hartina, 2009). Otonomi daerah juga memberikan otoritas kepada pemerintah daerah untuk mengelola keuangan daerahnya dalam melakukan pembangunan dan pelayanan kepada masyarakat.

Keuangan daerah merupakan hal yang sangat penting dalam menjalankan suatu organisasi atau pemerintahan. Pengelolaan keuangan adalah mengenai efisiensi dalam hal keuangan dan penggunaan yang efektif anggaran yang tersedia (Ojo, 2009). Pemerintah daerah harus secara hati-hati mengelola keuangan daerahnya guna mencegah terjadinya pengeluaran yang tidak tepat sasaran atau tidak perlu. Agar menghasilkan pengelolaan keuangan yang efektif, proses pengelolaan keuangan suatu daerah harus diatur sebaik mungkin sesuai dengan standar dan undang-undang yang telah ditetapkan.

Penelitian mengenai pengelolaan keuangan daerah sudah cukup banyak dilakukan di luar negeri. Penelitian yang dilakukan oleh Adebayo dan rekan (2014) mengenai penilaian pengelolaan keuangan dana pemerintah daerah yang efektif pada pemerintah daerah Ido-Osi di Nigeria. Hasil dari penelitian ini menyatakan bahwa ada sebuah kebutuhan darurat sistem pemerintahan daerah di Nigeria untuk mengembangkan mekanisme pengendalian keuangan mereka dan untuk merasionalkan pola-pola penggunaan anggarannya dari pada mencapai kinerja yang maksimal. Penelitian mengenai pengelolaan keuangan daerah sebelumnya juga telah dilakukan oleh Ojo (2009) yang membahas tentang peran pemerintah daerah dan mendefinisikan arti pengelolaan keuangan lebih sederhana yang dilanjutkan dengan pembahasan mengenai berbagai macam metode pengelolaan keuangan, instrumen pengelolaan keuangan, teknik pengelolaan keuangan seperti: penggunaan anggaran, pendekatan rasional, pendekatan incremental, dan lainnya.

Di Indonesia penelitian mengenai pengelolaan keuangan daerah telah banyak dilakukan. Penelitian mengenai pembaharuan pengelolaan keuangan sektor publik, studi kasus pada tiga pemerintah daerah di Indonesia, yaitu: pemerintah daerah Jakarta, Tangerang dan Pandeglang, oleh Mir dan Sutiyono (2013). Penelitian tersebut menemukan bahwa inisiatifinisiatif pembaruan tersebut telah gagal mencapai tujuan pengembangan transparansi dan akuntabilitas seperti yang diindikasikan oleh auditor publik. Hal itu ditemukan dalam pembaruan akuntansi sektor publik Indonesia, permintaan, persiapan, dan kualitas informasi akuntansi berada dalam keadaan tidak seimbang.

Penelitian lainnya mengenai pengelolaan keuangan daerah dilakukan oleh Suparno (2012), Saleba (2014) dan Rizki (2015). Penelitian-penelitian tersebut menemukan beberapa bukti empiris bahwa pengelolaan keuangan pemerintah daerah dipengaruhi oleh beberapa faktor. Akuntabilitas keuangan daerah merupakan salah satu faktor yang berpengaruh terhadap pengelolaan keuangan daerah. Penelitian terdahulu yang menguji pengaruh akuntabilitas keuangan daerah terhadap pengelolaan keuangan daerah adalah penelitian Suparno (2012) dan Rizki (2015). Hasil penelitan Rizki (2015) menyatakan akuntabilitas keuangan daerah berpengaruh secara signifikan terhadap pengelolaan keuangan daerah kabupaten Labuhan Batu, sedangkan hasil penelitian Suparno (2012) menyatakan bahwa akuntabilitas keuangan daerah tidak 
berpengaruh secara signifikan terhadap pengelolaan keuangan daerah kota Dumai.

Selain akuntabilitas keuangan daerah, Value for Money merupakan faktor yang diduga mempengaruhi pengelolaan keuangan daerah. Pada penelitian sebelumnya yang dilakukan oleh Suparno (2012) pada kota Dumai dan Rizki (2015) pada kabupaten Labuhan Batu menyatakan bahwa Value for Money tidak berpengaruh signifikan terhadap pengelolaan daerah.

Berdasarkan hasil dari penelitianpenelitian tersebut, ditemukan beberapa hasil penelitian yang berbeda dengan menggunakan variabel yang sama namun pada daerah yang berbeda. Hal ini mendorong peneliti untuk kembali melakukan pengujian mengenai akuntabilitas keuangan daerah dan Value for Money terhadap pengelolaan keuangan daerah pada daerah pemerintahan yang berbeda.

Penelitian ini merupakan pengembangan dari penelitian yang dilakukan oleh Suparno (2012) mengenai "Pengaruh Akuntabilitas Keuangan Daerah, Value for Money, Kejujuran, Transparansi, dan Pengawasan terhadap Pengelolaan Keuangan Daerah (Studi Kajian pada Pemerintah Kota Dumai)". Persamaan dengan penelitian Suparno (2012) adalah penggunaan variabel independen akuntabilitas keuangan daerah dan Value for Money serta variabel dependen pengelolaan keuangan daerah. Sedangkan, perbedaan dengan penelitian sebelumnya yaitu penelitian ini hanya menggunakan dua variabel independen akuntabilitas keuangan daerah dan Value for Money.

\section{Studi Literatur Pengertian Keuangan Daerah}

Keuangan Daerah tidak terlepas dan selalu terkait dengan anggaran pendapatan dan belanja daerah (APBD), karena keuangan daerah tersebut telah ditetapkan dalam APBD (Nordiawan, 2007).

Menurut Peraturan Pemerintah Republik Indonesia (PPRI) No. 58 tahun
2005, tentang Pengelolaan Keuangan Daerah menjelaskan bahwa Keuangan Daerah adalah semua hak dan kewajiban daerah dalam rangka penyelenggaraan pemerintah daerah yang dapat di nilai dengan uang termasuk didalamnya segala bentuk kekayaan yang berhubungan dengan hak dan kewajiban daerah tersebut dan tentunya dalam batas-batas kewenangan daerah, dan keuangan daerah dituangkan sepenuhnya ke dalam APBD.

Salah satu aspek dari pemerintah daerah yang harus diatur secara hati-hati adalah masalah pengelolaan keuangan daerah. Anggaran daerah atau Anggaran Pendapatan dan Belanja Daerah merupakan instrumen pengelolaan, anggaran pengelolaan menduduki porsi sentral dalam upaya pengembangan kapabilitas dan efektifitas pemerintah daerah. Anggaran daerah seharusnya dipergunakan sebagai alat untuk menentukan besarnya pendapatan dan pengeluaran, alat bantu pengambilan keputusan dan perencanaan pembangunan, alat otoritas pengeluaran dimasa yang akan datang. Ukuran standar untuk evaluasi kinerja serta alat koordinasi bagi semua aktivitas diberbagai unit kerja. Penentuan besarnya penerimaan/pendapatan dan pengeluaran/belanja daerah tidak terlepas dari peraturan perundang undangan yang berlaku. Mardiasmo (1999).

Anggaran Pendapatan dan Belanja Daerah (APBD) adalah anggaran pendapatan dan belanja daerah yang selanjutnya disingkat APBD merupakan rencana keuangan tahunan pemerintah daerah yang dibahas dan disetujui bersama oleh pemerintah daerah dan Dewan Perwakilan Rakyat Daerah (DPRD) dan ditetapkan dengan Peraturan Daerah (Perda) (PPRI No. 58 tahun 2005 tentang Pengelolaan Keuangan Daerah).

Perencanaan, pelaksanaan, penata usahaan, pelaporan, pertanggungjawaban, dan pengawasan keuangan daerah adalah merupakan seluruh rangkaian kegiatan dari pengelolaan Keuangan daerah/APBD oleh satuan kerja perangkat daerah (SKPD) 
sebagai pengguna keuangan daerah /APBD untuk pelayanan publik.

Sesuai Peraturan Menteri Dalam Negeri (Permendagri) Nomor 13 Tahun 2006, tentang Pedoman Pengelolaan Keuangan Daerah, pasal 311, menyebutkan bahwa (1) DPRD melakukan pengawasan terhadap pelaksanaan peraturan daerah (Perda) tentang APBD, (2) Pengawasan sebagaimana dimaksud pada ayat (1) bukan pemeriksaan tetapi pengawasan yang lebih mengarah untuk menjamin pencapaian sasaran yang telah ditetapkan dalam peraturan daerah tentang APBD, dan pasal 312 menyebutkan Pengawasan pengelolaan keuangan daerah berpedoman pada ketentuan peraturan perundang - undangan.

Akuntabilitas Keuangan

Akuntabilitas merupakan pertanggungjawaban dari pemegang amanah untuk mengelola, melaporkan dan mengungkapkan segala aktivitas yang berkaitan dengan amanah tersebut kepada pemberi amanah. Adanya akuntabibiltas dapat sebagai sarana/bukti bahwa suatu amanah sudah dikerjakan atau dilaksanakan dengan baik.

Akuntabilitas sebagai salah satu prinsip good governance berkaitan dengan pertanggungjawaban pimpinan atas keputusan dan hasil yang dicapai, sesuai dengan wewenang yang dilimpahkan dalam pelaksanaan tanggung jawab mengelola organisasi. Prinsip akuntabilitas digunakan untuk menciptakan sistem kontrol yang efektif berdasarkan distribusi kekuasaan pemegang saham, direksi, dan komisaris. Makna atau pengertian akuntabilitas dilihat dari aspek manajemen pemerintah, adalah sebagai berikut :

Menurut Rosjidi $(2011 ; 143)$ menyatakan bahwa akuntabilitas adalah : "Akuntabilitas adalah kewajibankewajiban dari individu-individu atau penguasa yang dipercayakan untuk mengelola sumber-sumber daya publik serta yang berkaitan dengan itu, guna menjawab hal-hal yang menyangkut pertanggungjawaban fiskal, manajerial, dan program atau kegiatan."

Sedangkan menurut Lembaga Administrasi Negara dan Badan Pengawasan Keuangan dan Pembangunan, (2000:43) dalam modul 1, makna akuntabilitas adalah sebagai berikut : "Akuntabilitas adalah kewajiban untuk memberikan pertanggungjawaban atau menjawab dan menerangkan kinerja dan tindakan seseorang / badan hukum / pimpinan suatu organisasi kepada pihak yang memiliki hak atau berkewenangan untuk meminta keterangan atau pertanggungjawaban".

Dari definisi di atas dapat ditarik empat materi kunci seperti yang dikutip Wasistiono (2012:53) yaitu sebagai berikut

a. Akuntabilitas adalah kewajiban sebagai konsekuensi logis dari adanya pemberian hak dan kewenangan;

b. Kewajiban tersebut berbentuk pertanggungjawaban terhadap kinerja dan tindakan;

c. Kewajiban tersebut melekat pada seseorang / badan hukun / pimpinan kolektif;

d. Pertanggungjawaban ditujukan kepada pihak-pihak yang memiliki hak dan berkewenangan untuk hal tersebut.

\section{Pengertian Value for Money}

Value for Money

(VFM)

merupakan konsep pengelolaan organisasi sektor publik yang mendasarkan pada tiga jenis elemen yaitu : ekonomi, efisiensi, dan efektifitas.(Renyowijoyo, 2008, dalam bukunya Mardiasmo (2002)). Ekonomi merupakan perolehan pemasukan (input) dengan kualitas dan kuantitas tertentu dengan harga terendah. Ekonomi merupakan perbandingan antara masukan yang terjadi dengan nilai masukan yang seharusnya. Ekonomi terkait dengan sejauh mana organisasi sektor publik dapat meminimalisisr sumber daya yang digunakan dengan menghindari pengeluaran yang boros dan tidak 
produktif. Efisiensi merupakan pencapaian keluaran (output) yang maksimum dengan masukan tertentu dengan penggunaan masukan terendah untuk mencapai keluaran tertentu. Efisiensi merupakan perbandingan keluaran/masukan (output/input) yang dikaitkan dengan standar kinerja atau target yang telah ditetapkan. Sedangkan efektifitas merupakan tingkat pencapaian hasil program dengan target yang ditetapkan. Secara sederhana efektifitas merupakan perbandingan Outcame dengan Output. Ketiga hal tersebut merupakan elemen pokok Value for Money (VFM) sedangkan tambahan dua elemen lain yaitu keadilan (Equity) dan pemerataan atau kesetaraan (Equality). Keadilan mengacu pada adanya kesempatan sosial (Social Opportunity) yang sama untuk mendapatkan pelayanan publik yang berkualitas dan kesejahteraan ekonomi. Selain keadilan perlu dilakukan distribusi secara merata (equality). Penggunaan publik hendaknya tidak hanya terkonsentrasi pada kelompok tertentu saja melainkan secara merata.

\section{Pengertian Pengawasan}

Pengawsan secara umum diartikan sebagai aktivitas pokok dalam manajemen untuk mengusahakan sedemikian rupa agar pekerjaan-pekerjaan terlaksana sesuai dengan rencana serta sesuai denagan hasil yang dikehendaki (Ibnu, 1982:41). Pada dasarnya pengawasan berlangsung mengikuti pola sebagai berikut :

a. Menetapkan standar atas dasar kontrol.

b. Mengukur hasil pekerjaan secepatnya.

c. Membandingkan hasil pekerjaan dengan standar atau dasar yang telah ditentukan semula.

d. Mengadakan tindakan koreksi

\section{Metode Penelitian}

Rancangan penelitian yang digunakan dalam penelitian ini adalah analisis data sekunder dengan tipe explanatory dan pendekatan berpikir dengan sistem kuantitatif.

Adapun yang menjadi objek penelitian sebagai variabel bebas (independent variable) adalah akuntabilitas keuangan daerah $\left(\mathrm{X}_{1}\right)$, Value for Money $\left(\mathrm{X}_{2}\right)$, dan pengawasan $\left(\mathrm{X}_{3}\right)$ sedangkan yang menjadi variabel terikat (dependent variable) adalah realisasi pengelolaan keuangan daerah (Y).

Pada penelitian ini, yang menjadi populasi adalah pejabat/aparatur Pemerintah Kota Banjarbaru yang terlibat langsung dalam realisasi pengelolaan keuangan daerah yaitu kepala dan pelaksana teknis disetiap SKPD Pemerintah Kota Banjarbaru. Sampel dalam penelitian ini adalah seluruh SKPD bidang keuangan yang pada Pemerintah Kota Banjarbaru maka sampel sebanyak 62 responden. Metode pengambilan sampel adalah sensus. Analisis regresi berganda merupakan regresi yang memiliki satu variabel dependen dan lebih dari satu variabel independen.

\section{Hasil Penelitian dan Pembahasan}

Hasil analisis regresi dengan menggunakan $\alpha$ sebesar 5\% diperoleh hasil pengujian sebagai berikut:

Tabel 1.

\section{Hasil Uji t (parsial)}

\begin{tabular}{|l|r|r|r|r|r|}
\hline & \multicolumn{2}{|c|}{$\begin{array}{c}\text { Unstandardized } \\
\text { Coefficients }\end{array}$} & $\begin{array}{c}\text { Standardized } \\
\text { Coefficients }\end{array}$ & & \\
\cline { 2 - 5 } Model & \multicolumn{1}{c|}{$\mathrm{B}$} & \multicolumn{1}{c|}{$\begin{array}{c}\text { Std. } \\
\text { Error }\end{array}$} & \multicolumn{1}{c|}{ Beta } & \multicolumn{1}{c|}{$\mathrm{t}$} & Sig. \\
\hline $\begin{array}{l}\text { 1(Constant) } \\
\text { Akuntabilitas }\end{array}$ & -1.515 & 2.330 & & -.650 & .518 \\
$\begin{array}{l}\text { Keuangan } \\
\text { Daerah }\end{array}$ & .815 & .054 & .865 & 15.010 & .000 \\
$\begin{array}{l}\text { Value For } \\
\text { Money } \\
\text { Pengawasan }\end{array}$ & -.015 & .034 & -.025 & -.441 & .661 \\
& .098 & .043 & .132 & 2.295 & .025 \\
\hline
\end{tabular}

a. Dependent Variable: Realisasi Pengelolaan Keuangan Daerah

Berdasarkan hasil analisis tersebut diatas, maka model persamaan regresi linier berganda yang dapat disusun sebagai berikut :

$\mathrm{Y}=3,424+1,585 \mathrm{X} 1-1,477 \mathrm{X} 2+0,691 \mathrm{X} 3+\mathrm{e}$ 
Berdasarkan pengolahan SPSS 22 yang telah dilakukan ats data yang diperoleh, dapat dilihat tabel berikut:

Tabel 2.

Koefisien Determinasi

Model Summaryb

\begin{tabular}{|c|c|c|c|c|c|}
\hline Model & $\mathrm{R}$ & $\begin{array}{c}\mathrm{R} \\
\text { Square } \\
\end{array}$ & $\begin{array}{l}\text { Adjusted } \\
\text { R Square }\end{array}$ & $\begin{array}{c}\text { Std. Error } \\
\text { of the } \\
\text { Estimate }\end{array}$ & $\begin{array}{l}\text { Durbin- } \\
\text { Watson }\end{array}$ \\
\hline 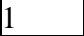 & $.907^{a}$ & .822 & .813 & 1.48273 & 1.916 \\
\hline
\end{tabular}

a. Predictors: (Constant), Pengawasan, Value For Money, Akuntabilitas Keuangan Daerah

b. Dependent Variable: Realisasi Pengelolaan Keuangan Daerah

Berdasarkan tabel diatas, hasil menunjukkan $\mathrm{R}$ (koefisien korelasi) = 0,822 yang berarti terjadi hubungan yang kuat antara variabel-variabel independen dengan variabel dependen sebesar 82,2\%.

Sedangkan, Adjusted R Square (koefisien determinasi) adalah suatu nilai yang menunjukkan kemampuan variabel bebas menjelaskan variabel terikat, dalam penelitian ini Adjusted R Square sebesar 0,813 yang berarti bawah $81,3 \%$ variasi (perubahan) Y (realisasi pengelolaan keuangan daerah) sedangkan sisanya $(100 \%-81,3 \%=18,7 \%)$ dijelaskan oleh sebab-sebab yang lain diluar model dalam penelitian ini

Uji T (parsial)

Hipotesis Pertama

Dari hasil pengujian $\mathrm{t}$ (parsial) variabel Akuntabilitas Keuangan Daerah (X1) diketahui nilai t hitung $=15,010$ lebih besar dari nilai $\mathrm{t}$ tabel $(1,999)$ dengan $\mathrm{p}$-value $0,000<0,05$ yang berarti bahwa secara parsial Akuntabilitas Keuangan Daerah (X1) berpengaruh terhadap Realisasi Pengelolaan Keuangan Daerah (Y), pada tingkat kepercayaan 95\%, sehingga hipotesis $\mathrm{H} 1$ diterima.

\section{Hipotesis Kedua}

Dari hasil pengujian t (parsial) variabel value for money (X2) diketahui nilai $t$ hitung = -,441 lebih kecil dari nilai t tabel $(1,999)$ dengan $p$-value $0,661>0,05$ yang berarti bahwa secara parsial value for money (X2) berpengaruh terhadap
Realisasi Pengelolaan Keuangan Daerah (Y), pada tingkat kepercayaan 95\%, sehingga hipotesis $\mathrm{H} 2$ ditolak.

\section{Hipotesis Ketiga}

Dari hasil pengujian $\mathrm{t}$ (parsial) variabel pengawas (X3) diketahui nilai $\mathrm{t}$ hitung $=$ 2,295 lebih besar dari nilai t tabel $(1,999)$ dengan $p$-value $0,000<0,026$ yang berarti bahwa secara parsial variabel pengawas (X3) berpengaruh terhadap Realisasi Pengelolaan Keuangan Daerah (Y), pada tingkat kepercayaan 95\%, sehingga hipotesis $\mathrm{H} 3$ diterima

Uji F (simultan)

Uji $\mathrm{F}$ digunakan untuk mengetahui apakah variabel-variabel independen secara simultan berpengaruh signifikan terhadap variabel dependen. Hasil Uji statistik $F$ dapat dilihat dari tabel dibawah ini :

Tabel 3.

\section{Hasil Uji f (simultan) \\ ANOVA $^{a}$}

\begin{tabular}{|l|l|l|l|l|l|}
\hline Model & $\begin{array}{l}\text { Sum of } \\
\text { Squares }\end{array}$ & df & $\begin{array}{l}\text { Mean } \\
\text { Square }\end{array}$ & F & Sig. \\
\hline 1 Regression & 590.359 & 3 & 196.786 & 89.510 & $.000^{\mathrm{b}}$ \\
Residual & 127.512 & 58 & 2.198 & & \\
Total & 717.871 & 61 & & & \\
\hline
\end{tabular}

a. Dependent Variable: Realisasi Pengelolaan Keuangan Daerah

b. Predictors: (Constant), Pengawasan, Value For Money, Akuntabilitas Keuangan Daerah

Dari hasil uji ANOVA atau uji F pada tabel diatas dapat dilihat bahwa $\mathrm{F}$ hitung sebesar 89,510 dan signifikansi $0,000<$ alpha 0,05 , hal ini menunjukkan bahwa F-hitung = $89,510>\mathrm{F}$ tabel 3,76 yang berarti Variabel independen Akuntabilitas Keuangan Daerah (X1), Value For Money (X2), dan Pengawasan (X3) terhadap Realisasi Pengelolaan Keuangan Daerah (Y), pada tingkat kepercayaan 95\%, sehingga hipotesis $\mathrm{H} 4$ diterima.

\section{Kesimpulan}


Setelah dilakukan analisis data dan pembahasan dapat ditarik kesimpulan sebagai berikut :

1. Terdapat pengaruh signifikan secara parsial antara variabel akuntabilitas keuangan daerah terhadap realisasi pengelolaan keuangan daerah di Pemerintah Kota Banjarbaru.

2. Tidak terdapat pengaruh signifikan secara parsial antara variabel value for Money terhadap realisasi pengelolaan keuangan daerah di Pemerintah Kota Banjarbaru.

3. Terdapat pengaruh signifikan secara parsial antara variabel pengawasan terhadap realisasi pengelolaan keuangan daerah di Pemerintah Kota Banjarbaru.

4. Terdapat pengaruh signifikan secara simultan antara variabel-variabel akuntabilitas keuangan daerah, value for Money, dan pengawasan terhadap realisasi pengelolaan keuangan daerah di Pemerintah Kota Banjarbaru.

Daftar Pustaka

Alamsyah, 1997. Mekanisme Pengawasan APBD di Kabupaten Sleman, Tesis MAP UGM, Yogykarta

Diana Halim Koencoro. 2004. Hukum Administrasi Negara, Ghalia Indonesia, Bogor

Fatchurrochman, Agam, 2002. Managemen Keuangan Publik, Materi Pelatihan Anti Korupsi, Indonesian Corruption Watch, Jakarta.

Ghozali Imam, 2006. Aplikasi Analisis Multivariate dengan Program SPSS, Edisi 4, Badan Penerbit Universitas Diponegoro, Semarang.

Halim, 2001. Managemen Keuangan Daerah, Yogyakarta UPP YKPN

Herma Yanti, SH.,MH., Mekanisme Pengawasan Terhadap Peraturan Daerah Menurut Undang-Undang Nomor 32 Tahun 2004
Ibnu Syamsi, 1982. Administrasi Perlengkapan Materiil Pemerintahan Daerah, Bina Aksara, Jakarta

Ihsan Rambe, 2003, Pengaruh Sistem Pengendalian Akuntansi Terhadap Kinerja Perusahaan Dengan Menggunakan Ketidakpastian Lingkungan Sebagai Variabel Moderating. Tesis. Universitas Sumatera Utara, Medan.

Instruksi Presiden No. 15 tahun 1983

Jogiyanto, 2004. Metodologi Penelitan Bisnis. Salah Kaprah dan Pengalaman Pengalaman, BPFE, Jorjakarta.

Jum Anggraini, Op.cit. 2012. Hukum Administrasi Negara, Graha Ilmu, Yogyakarta

Keputusan Presiden (Kepres) No. 74 tahun 2001 tentang tata cara pengawasan penyelenggaraan pemerintah daerah, pasal 1 ayat 6

Mahmudi. 2005. Manajemen Kinerja sektor publik. yogyakarta: UPP AMP YKPN

Mahoney, Thomas A., Thomas H. Jerdee, and Stephan J. Carrol, 1963, Development of Managerial Performance a Research Approact, Soutwestern Publishing

Mardiasmo, 1999. Akuntansi Sektor Publik. Jakarta. Erlangga.

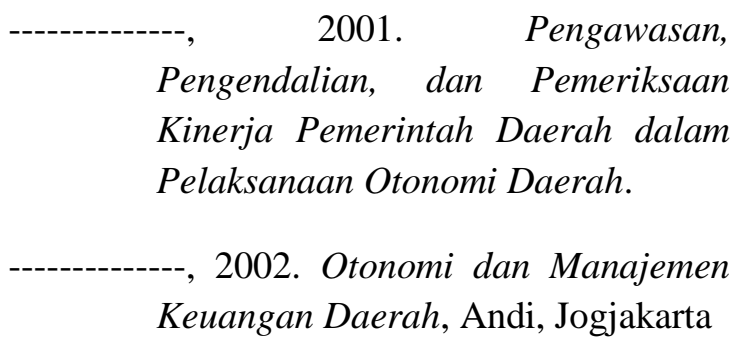

Maryono, Warella, Kismartini, 2007. Implementasi Kebijakan Pengelolaan Keuangan Daerah, Provinsi Jawa Tengah. 
Mas'Ud Fuad, 2004. Survei Diagnosis Organisasional Konsep dan Aplikasi, Badan Penerbit Universitas Diponegoro, Semarang.

MD Ihyaul Ulum, 2009. Audit Sektor Publik. Bumi Aksara, Jakarta.

Mulyana, Budi, 2006, Pengaruh Penyajian Neraca Daerah dan Aksesibilitas Laporan Keuangan Terhadap Transparansi dan Akuntabilitas Pengelolaan Keuangan Daerah Vol.2 No. 1, Mei : hal 65-78.

Noordiawan, Putra, Rahmawati, 2007. Akuntansi Pemerintahan. Salemba Empat, Jakarta.

Peraturan Menteri Dalam Negeri No. 13 tahun 2006. Tentang Pedoman Pengelolaan Keuangan Daerah. Jakarta

Peraturan Pemerintah Republik Indonesia No. 58 Tahun 2005 Tentang Pengelolaan Keuangan Daerah. Jakarta

Rawan Soejito, 1900. Hubungan Pemerintah Pusat Dan Pemerintah Daerah, Rineka Cipta, Jakarta

Renyowijoyo Muindro, 2008. Akuntansi Sektor Publik Organisasi Non Laba, Mitra Wacana Media. Jakarta.

Siregar, Liper, 2011. Pengaruh Akuntabilitas Publik dan Pengawasan Terhadap Pengelolaan APBD dengan Standar Akuntansi Pemerintahan sebagai Variabel Moderating pada Pemerintah Kota Pematang Siantar. Tesis, Universitas Sumatera Utara, Medan.

Soewarno Handayaningrat, 2004. Pengantar Studi Ilmu Administrasi Negara, Ghalia Indonesia, Bogor

Sopamah, Mardiasmo, 2003. Pengaruh Partisipasi Masyarakat dan Transparansi Kebijakan Publik
Terhadap Hubungan Pengetahuan Antara Pengetahuan Dewan Tentang Anggaran Dengan Pengawasan Keuangan Daerah, Simposium Nasional Akuntansi (SNA) VI 16 17 Oktober di Surabaya.

Sopanah, Isa Wahyudi, 2007. Pengaruh Akuntabilitas Publik, Partisipasi Masyarakat dan Transparansi Kebijakan Publik Terhadap Hubungan Antara Pengetahuan Anggaran dengan Pengawasan Keuangan Daerah (APBD). Jurnal Akuntansi.

Sugiyono, 1999. Metode Penelitian Bisnis. CV. Alfabeta, Bandung.

Sulistioni, G., 2003. Fiqh Korupsi : Amanah VS Kekuasaan, Somasi, Nusa Tenggara Barat.

Sumarsono, Hadi, 2009. Analisis kemandirian Otonomi Daerah. Jurnal Akuntansi Pemerintah Vol.1 No.1, 2009

Suriansyah Murhaini, 2014. Manajemen Pegawasan Pemerintahan Daerah, Pustaka Pelajar, Yogyakarta

Tuasikal, Askam, 2006. Pengaruh Pengawasan Internal dan Eksternal, Pemahaman Sistem Akuntansi Terhadap Pengelolaan Keuangan Daerah, Serta ImplikasinyaTerhadap Kinerja Unit Satuan Kerja Perangkat Daerah. Disertasi. Universitas Padjajaran Bandung.

Umar Husein, 2009. Riset Akuntansi Terapan, Galia Indenesia, Jakarta 